\title{
Household Wealth: Has It Recovered?
}

\author{
William T. Gavin, Vice President and Economist
}

$\mathrm{T}$ he 2012:Q4 flow of funds data released on March 7, 2013, by the Federal Reserve reported that the net worth of households and nonprofit organizations rose to $\$ 66.1$ trillion. ${ }^{1}$ Taking this as a measure of household wealth, the financial press reported that household wealth had risen to within 2 percent of its previous (pre-recession) peak in 2007:Q3. Determining whether households are nearly as wealthy now as then is complicated. Hard-to-measure factors, such as human capital, the distribution of wealth, and the tax liabilities of the wealthy, could be considered in a more extensive analysis. Here, I make a determination that depends on some factors more easily measured-population growth, inflation, and a riskfree real interest rate. The risk-free real interest rate matters because it determines how large the flow of future real consumption guaranteed from a given amount of wealth can be.

I use the chain price index for personal consumption expenditures (PCE) to deflate nominal household wealth. I also divide total wealth by the population of the United States. To account for changes in the real interest rate, I assume a representative household that wants a constant monthly income for the next 10 years. The household invests in a 10-year annuity indexed for inflation with no default risk. The inflation-adjusted risk-free real interest rate is measured by the rate on long-term Treasury inflationprotected securities (TIPS). Annuity payments are similar to mortgage payments. For example, when a bank makes a 10 -year conventional fixed-rate mortgage loan, it receives a fixed amount each month for 120 months, at which time the mortgage is paid off and monthly payments end. An annuity pays the holder in a similar fashion.

\section{Adjusting for inflation, population growth, and a risk-free real interest rate shows there is still a substantial gap between the peak of household wealth in 2007 and the level today.}

The table shows the different measures of household wealth-the interest rate on long-term TIPS and the per capita levels of real PCE-for three particular quarters: 2007:Q3, when the flow of funds measure of household wealth peaked; 2009:Q2, when the recession ended and

\section{Measures of Household Wealth and Real Consumption}

\begin{tabular}{|c|c|c|c|c|c|c|}
\hline Period & $\begin{array}{l}\text { Household wealth } \\
\text { (\$ billions) }\end{array}$ & $\begin{array}{c}\text { Per capita real } \\
\text { household wealth } \\
\text { (current \$) }\end{array}$ & $\begin{array}{c}\text { Per capita real } \\
\text { household wealth } \\
\text { (2005\$) }\end{array}$ & $\begin{array}{l}\text { Real monthly income } \\
\text { from a } 10 \text {-year } \\
\text { fixed annuity } \\
\text { (\$) }\end{array}$ & $\begin{array}{l}\text { Long-term } \\
\text { risk-free real } \\
\text { interest rate } \\
(\%)\end{array}$ & $\begin{array}{l}\text { Monthly } \\
\text { per capita } \\
\text { real PCE } \\
(\$)\end{array}$ \\
\hline 2007:Q3 & 67,413 & 223,176 & 211,063 & 1,978 & 2.38 & 2,562 \\
\hline 2009:Q2 & 52,495 & 171,067 & 157,671 & 1,476 & 2.35 & 2,444 \\
\hline 2012:Q4 & 66,072 & 209,643 & 180,087 & 1,501 & $0.00^{*}$ & 2,555 \\
\hline
\end{tabular}

NOTE: Household wealth is the net worth of household and nonprofit organizations measured in billions of dollars. Population is the total civilian and institutionalized population of the United States. The per capita real household wealth measure is calculated by deflating the current dollar value by the chain price index for PCE. Monthly income from a 10-year fixed annuity is calculated using a measure of the long-term real interest rate on TIPS from the St. Louis Fed's Federal Reserve Economic Data (FRED) website. *The rate was -0.09 percent in 2012:Q4 but assumed to be zero for simplicity.

SOURCE: FRED; http://research.stlouisfed.org/fred2/. 
that measure troughed; and 2012:Q4, the most recent quarter for which the data are available.

As shown in the first column, aggregate household wealth in 2012:Q4 was $\$ 66.1$ trillion, 26 percent higher than the end-of-recession level and only 2 percent lower than the 2007 peak. After adjusting for population growth, it is still 23 percent higher than the 2009 trough but 6 percent lower than the pre-recession peak. Inflation has been modest, but it makes real wealth appear even lower today. Per capita real household wealth in 2012:Q4 was just 14 percent above the 2009 trough and 15 percent below the 2007 peak. The TIPS interest rate in 2007:Q3 (the fifth column in the table) was 2.38 percent-near its 2.35 percent end-ofrecession trough-but fell to -0.09 percent in 2012:Q4. (For simplicity, as shown in the table, I assume that the rate was zero in 2012:Q4.) Based on the TIPS interest rate, the annuity value of household wealth in 2012:Q4 was just 1.7 percent above its end-of-recession trough but still 24 percent below its 2007 peak.
An interesting observation emerges when the artificial 10-year annuity is compared with the monthly average of per capita real PCE. The comparison shows that monthly income from household wealth would have been 77 percent of per capita real PCE in 2007:Q3, just 60 percent by the end of the recession, and an even lower 58 percent by 2012:Q4. Although flow of funds data suggest household wealth has nearly rebounded to its pre-recession peak, adjusting for inflation, population growth, and a risk-free real interest rate shows there is still a substantial gap between the peak of household wealth in 2007 and the level today.

\section{Note}

1 See line 42 in the March 7, 2013, data release for the Balance Sheets of Households and Nonprofit Organizations; http://www.federalreserve.gov/releases/z1/Current/z1r-5.pdf. 